\title{
Antioxidant activity and total phenolic contents of Galanthus woronowii (Amaryllidaceae)
}

\author{
Galanthus woronowii (Amaryllidaceae)'nin antioksidan aktivitesi ve toplam fenolik içeriği

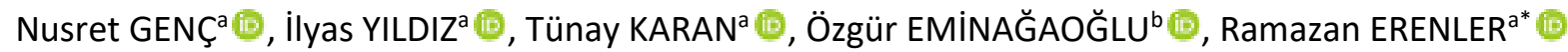 \\ a Plant Research Laboratory, Department of Chemistry, Faculty of Arts and Sciences, Tokat Gaziosmanpasa University, Tokat, Turkey \\ ${ }^{b}$ Department of Forest Engineering, Faculty of Forestry, Artvin Coruh University, Artvin, Turkey
}

\begin{abstract}
Article Info
(C)2018 Ali Nihat Gökyiğit Botanical Garden Application and Research Center of Artvin Coruh University.

*Corresponding author:

e-mail: ramazan.erenler@gop.edu.tr ORCID: 0000-0002-0505-3190

Article history

Received: January 20, 2019

Received in revised form: January 30, 2019

Accepted: January 31, 2019

Available online: February 01, 2019
\end{abstract}

(c) (i) This is an Open Access article under the CC BY license (http://creativecommons.org/licenses /by/4.0/).

\section{Keywords:}

Galanthus woronowii, antioxidant activity, natural product, phenolic contents.

\section{Anahtar kelimeler:}

Galanthus woronowii, antioksidan aktivite, doğal ürün, fenolik içerik.

\begin{abstract}
Plants have been used for medicinal purpose since ancient times. Due to the including bioactive secondary metabolites, plants have gained the great interest for drug discovery and development process. In this work, Galanthus woronowii was extracted with hexane, dichloromethane and ethyl acetate sequentially. After removing of the solvent by rotary evaporator, crude extracts were yielded. Antioxidant activity including 1,1-diphenyl-2-picrylhydrazyl (DPPH), 2,2'-azino-bis(3ethylbenzothiazoline-6-sulphonic acid) (ABTS) and reducing power assays were executed on corresponding extracts. In addition, total phenolic content was presented. Ethyl acetate extract included the most phenolic compounds and also it revealed the most antioxidant activity. Hence, this plant could be considered as a promising antioxidant agent.
\end{abstract}

\section{öz}

Bitkiler eski çağlardan beri tıbbi amaçlarla kullanılmaktadır. İçerdikleri biyoaktif sekonder metabolitlerden dolayı, bitkiler ilaç keşfi ve gelişimi için oldukça fazla ilgi görmektedir. Bu çalışmada, Galanthus woronowii türüne ait bitki materyalleri sırasıyla hekzan, diklorometan ve etil asetat ile ekstrakte edilmiştir. Çözücü dönerli buharlaştıııcı ile uzaklaştırıldıktan sonra ham ekstraktlar elde edilmiştir. Ekstraktların DPPH serbest radikal giderme, ABTS radikal katyon giderme ve indirgeme gücü aktiviteleri değerlendirilmiştir. Ayrıca toplan fenolik içerik belirlenmiştir. Etil asetat ekstraktının en çok fenolik içerdiği ve en yüksek antioksidan aktivite gösterdiği belirlenmiştir. Bu nedenlerle, bu bitki ümit verici antioksidan ajan olarak kabul edilebilir.

\section{Citation:}

To cite this article: Genç N, Yıldız I, Karan T, Eminağaoğlu Ö, Erenler R (2019). Antioxidant activity and total phenolic contents of Galanthus woronowii (Amaryllidaceae). Turk J Biod 2(1): 1-5.

\section{INTRODUCTION}

Plants have been used for treatment of ailment since ancient times (Aksit et al., 2014; Demirtas et al., 2013; Topçu et al., 1999; Yaglıoglu et al., 2013). They included secondary metabolites revealing a great many biological activities (Elmastas et al., 2016; Erenler, Pabuccu, et al., 2016; Erenler, Sen, Yaglioglu, et al., 2016; Erenler, Sen, Yildiz, et al., 2016). A large number of medicines include natural products as main active ingredients (Erenler,
Demirtas, et al., 2017; Erenler et al., 2018; Karan \& Erenler 2017, 2018; Karan et al., 2018). Due to the including of bioactive compounds, isolation and identification of corresponding compounds have gained the great interest lately. Since the natural compounds have a little or lack of side effect as a drug, they inspired to synthetic chemists to synthesize natural compounds for pharmaceutical industry (Erenler, Meral, et al., 2017; Karan et al., 2017). 
The Galanthus L. genus (Amaryllidaceae family) is represented by 14 species (15 taxa) and 1 hybrid. This genus known as snowdrops is perennial oniony petal liliopsida. Galanthus woronowii Losink. is distributed through north-eastern part of Turkey (Davis, 2006). Amaryllidaceae family is one of the significant alkaloid containing plant family in the world. A great many alkaloids were isolated and identified from Galanthus species. Hence Galanthus genus can be accepted as a rich source of chemically diverse alkaloids (Jin, 2013).

Previous phytochemical investigations were reported that alkaloids such as galanthusine, lycorine, galanthine, demethylhomolycorine were isolated and identified from G. woronowii (Kintsurashvili \& Vachnadze, 2007). The alkaloids, narwedine, O-methylleucotamine, sternbergine, and sanguinine isolated from $G$. woronowii displayed the considerable acetylcholinesterase (AChE) inhibitory activity (Sarikaya et al., 2013). G. woronowii has been used in homeopathy and has been prepared from fresh whole flowering plants (Bokov \& Samylina, 2016). Galanthamine is an alkaloid isolated from $G$. woronowii (snowdrop). It is a licensed medicine for the treatment of Alzheimer's disease. Inhibition of AChE selectively and competitively is considered the principal mode of action of galanthamine and it increased nicotinic acetylcholine receptor function (Howes \& Perry, 2011).

Reactive oxygen species such as superoxide $\left(\mathrm{O}_{2}{ }^{--}\right)$, peroxyl $\left(\mathrm{ROO}^{\circ}\right)$, peroxinitrite $\left(\mathrm{ONOO}^{\circ}\right)$, hydroxyl $\left(\mathrm{OH}^{{ }^{-}}\right)$ and nitric oxide $\left(\mathrm{NO}^{\circ}\right)$ are free radicals that yielded during oxidative function within the body (Koysu et al., 2018). The human body has some protection systems against oxidative stress, including antioxidant enzymes and chemical compounds. Exposure to various environmental pollutants such as smoking, bad living conditions, malnutrition, ultra violet radiation leads to natural antioxidant to be inadequate. Therefore, the excess free radicals can harm to cell membrane during the metabolism leading to degenerative illness and conditions such as Alzheimer's disease, cardiovascular disease, liver toxicity, ageing process, nephroblast, diabetes, inflammation and DNA injury leading to carcinogenesis. Antioxidants play a significant role in quenching singlet oxygen, deactivating free radicals, inhibiting peroxidation, releasing hydrogen, and chelating metal ion (Erenler et al., 2015). Therefore, many antioxidant based medicines have been applied to prevent and treat the corresponding diseases. Recently, considerable studies have been carried out in discovering natural antioxidants for use in food, cosmetics, and active ingredient for medicine to replace synthetic antioxidants which have been prohibited due to their carcinogenic effects (Sasaki et al., 2002). Herein, it was investigated the antioxidant activities of $G$. woronowii extracts using $\mathrm{DPPH}^{\bullet}, \mathrm{ABTS}^{\circ}$, and reducing power assays.

\section{MATERIAL AND METHOD}

\subsection{General experimental procedures}

Hitachi U-290 UV-VIS spectrophotometer was used for UV analysis. 1,1-diphenyl-2-picrylhydrazyl (DPPH), 2,2'azino-bis(3-ethylbenzothiazoline-6-sulphonic acid) diammonium salt (ABTS), butlylated hydroxyanisole (BHA), butlylaed hydroxytoluene (BHT), trolox, amonyum acetate $\left(\mathrm{NH}_{4} \mathrm{CO}_{2} \mathrm{CH}_{3}\right)$, potassium persulphate $\left(\mathrm{K}_{2} \mathrm{~S}_{2} \mathrm{O}_{8}\right)$ were bought from Sigma (Sigma-Aldrich $\mathrm{GmbH}$ Steinheim, Germany). The solvents with analytical grade, potassium dihydrogen phosphate $\left(\mathrm{KH}_{2} \mathrm{PO}_{4}\right)$, potassium hydroxide $(\mathrm{KOH})$, cupper (II) chloride $\left(\mathrm{CuCl}_{2}\right)$, FolinCiocalteu reagent, gallic acid were supplied from E. Merck (Darmstadt, Germany).

\subsection{Plant material}

Galanthus woronowii was collected from Arhavi, Artvin, Turkey during the flowering period in July 2018 and identified by Prof. Dr. Özgür Eminagaoglu, specialists of Plant Taxonomy (ARTH 13436).

\subsection{Extraction}

G. woronowii $(200 \mathrm{~g})$ was extracted with hexane $(3 \times 200$ $\mathrm{mL})$, dichloromethane $(3 \times 200 \mathrm{~mL})$ and ethyl acetate $(3 \times$ $200 \mathrm{~mL}$ ) sequentially for 3 days. After removing of solvent from each extract solution under reduced pressure, the crude extracts were yielded. The each extract was kept in fridge $\left(+4{ }^{\circ} \mathrm{C}\right)$ for antioxidant analysis (Erenler et al., 2014).

\subsection{Total phenolic determination}

Total phenolic content of hexane-, dicloromethane-, and ethyl acetate extracts of Galanthus woronowii was carried out by Folin-Ciocalteu reagent using gallic acid as a standard (Singleton \& Slinkard, 1977). The treatment of extract solution ( $1.0 \mathrm{~mL}$, containing $1.0 \mathrm{mg}$ sample) with Folin-Ciocalteu reagent $(0.1 \mathrm{~mL})$ in distilled water $(4.6 \mathrm{~mL})$ was carried out in a volumetric flask. Sodium carbonate $\left(\mathrm{Na}_{2} \mathrm{CO}_{3}\right)$ solution was added to the reaction flask then incubated for $2 \mathrm{~h}$ at room temperature. The absorbance 
measurement was executed at $765 \mathrm{~nm}$ by a spectrophotometer (Hitachi U-2900). The standard curve was calculated using gallic acid and the results were presented as gallic acid equivalents per mg of extract (Elmastaş et al., 2015). All experiments were carried out in triplicate.

\subsection{DPPH free radical scavenging assay}

DPPH free radical scavenging effects of hexane-, dichloromethane- and ethyl acetate extracts of $G$. woronowii were executed (Blois, 1958). Different concentrations of each extract $(3 \mathrm{~mL})$ were treated with $\mathrm{DPPH}^{\circ}(1.0 \mathrm{~mL}, 0.26 \mathrm{mM})$ for $15 \mathrm{~min}$ at room temperature. The absorbance was recorded at $517 \mathrm{~nm}$. The experiment was repeated for three times. BHA, BHT and Trolox were used as standard controls. $I C_{50}$ values indicate the concentration of sample that scavenges $50 \%$ of DPPH free radical. The DPPH ${ }^{\circ}$ scavenging activity was calculated using the equation:

$\mathrm{DPPH}^{*}$ scavenging effect $(\%)=[(\mathrm{Ac}-\mathrm{As}) / \mathrm{Ac}] \times 100$

$A c$ is the absorbance of the control and $A s$ is the absorbance of the sample (Elmastas et al., 2004). The results were calculated as $\mathrm{IC}_{50}$.

\subsection{ABTS radical cation scavenging assay}

Antioxidant activity of extracts were determined using the trolox equivalent antioxidant capacity assay with the radical cation $\mathrm{ABTS}^{\circ+}$ as reported previously (Re et al., 1999). ABTS $^{*+}$ stock solution was prepared by the treatment of ABTS $(2 \mathrm{mM})$ with potassium persulfate $(2.45 \mathrm{mM})$. Afterward, it was stored for $6 \mathrm{~h}$ in dark at room temperature. $\mathrm{ABTS}^{\circ+}$ solution $(1.0 \mathrm{~mL})$ treated with each sample solution $(3.0 \mathrm{~mL})$. The inhibition was calculated for each concentration comparative to a blank absorbance. The absorbance was determined at $734 \mathrm{~nm}$. The capacity of $\mathrm{ABTS}^{\cdot+}$ was calculated by the equation: ABTS $^{*+}$ scavenging effect $(\%)=\left[\left(A_{1}-A_{2}\right) / A_{1}\right] \times 100$ in which, $A_{1}$ is $A B T S^{\circ+}$ initial concentration and $A_{2}$ is $A B T S^{\circ+}$ remaining concentration in the sample. The results were calculated as $\mathrm{IC}_{50}$.

\subsection{Cupric ion reducing power assay}

Cupric ion reducing power test was carried out on hexane-, dichloromethan- and ethyl acetate extracts of $G$. woronowii (Elmastas et al., 2018). Antioxidant extract reduced the $\mathrm{Cu}^{+2}$ to $\mathrm{Cu}^{+1}$. Yellow color complex formed after addition of $\mathrm{CuCl}_{2}$ to the reaction medium. Afterward the absorbance of corresponding complex was recorded. In this assay, each extract $(40-160 \mu \mathrm{g} / \mathrm{mL}, 1.0 \mathrm{~mL})$ was mixed with $\mathrm{CuCl}_{2}(0.01 \mathrm{M}, 1.0 \mathrm{~mL})$, neocuproine $(1.0 \mathrm{~mL}$, $\left.7.5 \times 10^{-3} \mathrm{M}\right)$, and acetate tampon $(1.0 \mathrm{~mL}, 1.0 \mathrm{M})$ solution. Neocuproine and $\mathrm{CuCl}_{2}$ were dissoved in $\mathrm{EtOH}$ and water respectively. After incubation of reaction mixture for $30 \mathrm{~min}$, the absorbance was recorded at $\mathbf{4 5 0}$ nm (Apak et al., 2004). The result was expressed according to the Trolox equivalent ( $\mu \mathrm{mol} / \mathrm{g}$ sample).

\section{RESULTS}

Phenolic compounds are a large class of plant secondary metabolites and importand for quality of plant based foods (Erenler, Adak et al., 2017). Aerial part of the $G$. woronowii was extracted with hexane, dichloromethane and ethyl acetate sequentially to yield the crude extracts. Antioxidant activity assays including $\mathrm{DPPH}^{\bullet}$ scavenging activity, $\mathrm{ABTS}^{+\bullet}$ scavenging effect and cupric ion reducing power activity were executed on corresponding extracts. In addition, total phenolic contents were presented. It was observed that there was a correlation between phenolic content and antioxidant activity. Total phenolic content of hexane-, dichloromethane- and ethyl acetate extracts were found as $51.05 \mathrm{mg} \mathrm{GA} / \mathrm{g}$ extract, $63.81 \mathrm{mg}$ $\mathrm{GA} / \mathrm{g}$ extract, $83.33 \mathrm{mg} \mathrm{GA} / \mathrm{g}$ extract respectively (Table 1).

Table 1. Antioxidant activity of Galanthus woronowii extracts

\begin{tabular}{|c|c|c|c|c|}
\hline $\begin{array}{l}\text { Extracts and } \\
\text { standards }\end{array}$ & $\begin{array}{l}\text { Total phenolic contents } \\
\text { (mg GAE/g extract) }\end{array}$ & $\begin{array}{l}\text { DPPH }^{\circ} \text { scavenging [IC } \\
(\mu \mathrm{g} / \mathrm{mL})]\end{array}$ & $\begin{array}{l}\text { CUPRAC ( } \mu \mathrm{mol} \\
\mathrm{TE} / \mathrm{mg} \text { extract) }\end{array}$ & $\begin{array}{l}\text { ABTS }{ }^{\circ+} \text { Scavenging } \\
{\left[\mathrm{IC}_{50}(\mu \mathrm{g} / \mathrm{mL})\right]}\end{array}$ \\
\hline Hexane ext & $51.05 \pm 5.86$ & $69.07 \pm 0.42$ & $0.49 \pm 0.03$ & $28.51 \pm 1.27$ \\
\hline $\mathrm{CH}_{2} \mathrm{Cl}_{2}$ ext & $63.81 \pm 4.12$ & $34.63 \pm 0.210 .21$ & $0.98 \pm 0.17$ & $16.84 \pm 0.49$ \\
\hline EtOAc ext & $83.33 \pm 3.60$ & $28.14 \pm 0.40$ & $0.72 \pm 0.01$ & $13.09 \pm 0.20$ \\
\hline BHT & - & $9.92 \pm 0.23$ & $3.63 \pm 0.18$ & $5.38 \pm 0.18$ \\
\hline $\mathrm{BHA}$ & - & $5.37 \pm 0.21$ & $2.87 \pm 0.18$ & $8.80 \pm 0.06$ \\
\hline Trolox & - & $5.77 \pm 0.12$ & - & $5.57 \pm 0.09$ \\
\hline
\end{tabular}


In term of activity, ethyl acetate extract $\left(\mathrm{IC}_{50}, 28.14\right.$ $\mu \mathrm{g} / \mathrm{mL}$ ) revealed the most DPPH free radical scavenging effect among the extract. But this value indicated the moderate activity in comparison to $\mathrm{BHT}\left(\mathrm{IC}_{50}, 9.92\right.$ $\mu \mathrm{g} / \mathrm{mL}$ ). Ethyl acetate extract was also exhibited the most $\mathrm{ABTS}^{+\bullet}$ scavenging effect with the value of 13.09 (IC $\mathrm{C}_{50}$, $\mu \mathrm{g} / \mathrm{mL})$ than that of the hexane extract $\left(I C_{50}, 28.51 \mu \mathrm{g} / \mathrm{mL}\right)$ and dichloromethane extract $\left(\mathrm{IC}_{50}, 16.84 \mu \mathrm{g} / \mathrm{mL}\right)$. Ethyl acetate extracts of herbal plants consist of flavonoids displaying significant antioxidant activity (Chhikara et al., 2018; Guzel et al., 2017). This could be due to the hydrogen or electron releasing ability of corresponding flavonoids (Erenler, Sen, Aksit, et al., 2016). In reducing power assay, dichloromethan extract exhibited the considerable effect $(0.98 \mu \mathrm{mol} \mathrm{TE} / \mathrm{mg}$ extract) among the hexane $(0.49 \mu \mathrm{mol} \mathrm{TE} / \mathrm{mg}$ extract) extract and ethyl acetate extract $(0.72 \mu \mathrm{mol} \mathrm{TE} / \mathrm{mg}$ extract). Interestingly, dichloromethane extract displayed the more reducing power effect than ethyl acetate extract. Although, dichloromethane extract included the less phenolic compounds than that of the ethyl acetate extract. This incident could be explained either the synergic effect of the compounds found in the extract or a compound in the extract reduced the cupper ion selectively.

\section{CONCLUSIONS}

Secondary metabolites of $G$. woronowii extracts should be isolated and identified to display the exact mechanism of activity. In addition, $G$. woronowii has a potency to be used in pharmaceutical and food industry as a natural antioxidant. The cultivation of $G$. woronowii should be carried out in a large scale. In addition, the isolated compounds as well as plant extracts of $G$. woronowii should be investigated for various biological effects.

\section{Acknowledgments}

The authors thank to the Scientific and Research Council of Tokat Gaziosmanpasa University (BAP No: 2017/31).

\section{REFERENCES}

Aksit H, Çelik SM, Sen Ö, Erenler R, Demirtas I, Telci I, Elmastas M (2014). Complete isolation and characterization of polar portion of Mentha dumetorum water extract. Records of Natural Products 8: 277-280.

Apak R, Güçlü K, Özyürek M, Karademir SE (2004). Novel total antioxidant capacity index for dietary polyphenols and vitamins $\mathrm{C}$ and $\mathrm{E}$, using their cupric ion reducing capability in the presence of neocuproine: CUPRAC method. Journal of Agricultural and Food Chemistry 52: 7970-7981.
Blois MS (1958). Antioxidant determinations by the use of a stable free radical. Nature 181: 1199-1200.

Bokov D, Samylina I (2016). Identification of Flavonoids in Homeopathic Mother Tinctures of Galanthus woronowii Losinsk. And Galanthus nivalis L. by Ultra-Performance Liquid Chromatography with Photodiode Arrays and Tandem Quadrupole Mass-Selective Detectors. Pharmaceutical Chemistry Journal 50: 458-464.

Chhikara N, Kushwaha K, Sharma P, Gat Y, Panghal A (2018). Bioactive compounds of beetroot and utilization in food processing industry: A critical review. Food Chemistry 272: 192-200.

Davis AP (2006). The Genus Galanthus-snowdrops in the wild. In: Snowdrops, A Monograph of Cultivated Galanthus. Cheltenham: Griffin Press Publishing Ltd. pp. 9-63.

Demirtas I, Erenler R, Elmastas M, Goktasoglu A (2013). Studies on the antioxidant potential of flavones of Allium vineale isolated from its water-soluble fraction. Food Chemistry 136: 34-40.

Elmastas M, Celik SM, Genc N, Aksit H, Erenler R, Gulcin I (2018). Antioxidant activity of an Anatolian herbal tea-Origanum minutiflorum: isolation and characterization of its secondary metabolites. International Journal of Food Properties 21: 374-384.

Elmastas M, Erenler R, Isnac B, Aksit H, Sen O, Genc N, Demirtas I (2016). Isolation and identification of a new neo-clerodane diterpenoid from Teucrium chamaedrys L. Natural Product Research 30: 299-304.

Elmastas M, Ozturk L, Gokce I, Erenler R, Aboul-Enein HY (2004). Determination of antioxidant activity of marshmallow flower (Althaea officinalis L.). Analytical Letters 37: 1859-1869.

Elmastaş M, Telci i, Akşit H, Erenler R (2015). Comparison of total phenolic contents and antioxidant capacities in mint genotypes used as spices/Baharat olarak kullanılan nane genotiplerinin toplam fenolik içerikleri ve antioksidan kapasitelerinin karşılaştırılması. Turkish Journal of Biochemistry 40: 456-462.

Erenler R, Adak T, Karan T, Elmastas M, Yildiz I, Aksit H, Topcu G, Sanda MA (2017). Chemical Constituents isolated from Origanum solymicum with Antioxidant activities. The Eurasia Proceedings of Science, Technology, Engineering \& Mathematics 1: 139-145.

Erenler R, Demirtas I, Karan T, Altun M, Gul F (2017). Inhibitory Effect of 6, 7-dimethoxy-5-hydroxyflavone on Human Cervix Carcinoma in Vitro. International Journal of Secondary Metabolite (IJSM) 4: 512-516.

Erenler R, Meral B, Sen O, Elmastas M, Aydin A, Eminagaoglu O, Topcu $G$ (2017). Bioassay-guided isolation, identification of compounds from Origanum rotundifolium and investigation of their antiproliferative and antioxidant activities. Pharmaceutical Biology 55: 1646-1653.

Erenler R, Pabuccu K, Yaglioglu AS, Demirtas I, Gul F (2016). Chemical constituents and antiproliferative effects of cultured Mougeotia nummuloides and Spirulina major against cancerous cell lines. Zeitschrift für Naturforschung C 71: 87-92.

Erenler R, Sen O, Aksit H, Demirtas I, Yaglioglu AS, Elmastas M, Telci i (2016). Isolation and identification of chemical constituents from Origanum majorana and investigation of antiproliferative and antioxidant activities. Journal of the Science of Food and Agriculture 96: 822-836.

Erenler R, Sen O, Yaglioglu AS, Demirtas I (2016). Bioactivity-guided isolation of antiproliferative sesquiterpene lactones from Centaurea solstitialis L. ssp. solstitialis. Comb Chem High Throughput Screen 19: 66-72. 
Erenler R, Sen O, Yildiz I, Aydin A (2016). Antiproliferative activities of chemical constituents isolated from Thymus praecox subsp grossheimii (Ronniger) Jalas. Records of Natural Products 10: 766770.

Erenler R, Telci I, Elmastaş M, Akşit H, Gül F, Tüfekçi AR, Demirtaş i, Kayir Ö (2018). Quantification of flavonoids isolated from Mentha spicata in selected clones of Turkish mint landraces. Turkish Journal of Chemistry 42: 1695-1705.

Erenler R, Telci I, Ulutas M, Demirtas I, Gul F, Elmastas M, Kayir O (2015). Chemical Constituents, Quantitative Analysis and Antioxidant Activities of Echinacea purpurea (L.) Moench and Echinacea pallida (Nutt.) Nutt. Journal of Food Biochemistry 39: 622-630.

Erenler R, Yilmaz S, Aksit H, Sen O, Genc N, Elmastas M, Demirtas I (2014). Antioxidant activities of chemical constituents isolated from Echinops orientalis Trauv. Records of Natural Products 8 (1): 32-36.

Guzel A, Aksit H, Elmastas M, Erenler R (2017). Bioassay-guided isolation and identification of antioxidant flavonoids from Cyclotrichium origanifolium (Labill.) Manden. and Scheng. Pharmacognosy Magazine 13(50):316-320.

Howes M-JR, Perry E (2011). The role of phytochemicals in the treatment and prevention of dementia. Drugs \& Aging 28: 439468.

Jin Z (2013). Amaryllidaceae and Sceletium alkaloids. Natural Product Reports 30: 849-868.

Karan T, Altuner Z, Erenler R (2017). Growth and Metabolite Production of Chroococcus minutus Under Different Temperature and Light Conditions. Journal of New Results in Science 6: 47-52.

Karan T, Erenler R (2018). Fatty acid constituents and anticancer activity of Cladophora fracta (OF Müller ex Vahl) Kützing. Tropical Journal of Pharmaceutical Research 17: 1977-1982.

Karan T, Erenler R (2017). Screening of norharmane from seven cyanobacteria by high-performance liquid chromatography. Pharmacognosy Magazine 13: 723-725.
Karan T, Yildiz I, Aydin A, Erenler R (2018). Inhibition of various cancer cells proliferation of bornyl acetate and essential oil from Inula graveolens (Linnaeus) Desf. Records of Natural Products 12: 273283.

Kintsurashvili L, Vachnadze V (2007). Plants of the Amaryllidaceae family grown and introduced in Georgia: a source of galanthamine. Pharmaceutical Chemistry Journal 41: 492-494.

Koysu P, Genc N, Elmastas M, Aksit H, Erenler R (2018). Isolation, identification of secondary metabolites from Salvia absconditiflora and evaluation of their antioxidative properties. Natural Product Research 16: 1-4.

Re R, Pellegrini N, Proteggente A, Pannala A, Yang M, Rice-Evans C (1999). Antioxidant activity applying an improved ABTS radical cation decolorization assay. Free Radical Biology and Medicine 26: 1231-1237.

Sarikaya BB, Kaya GI, Onur MA, Bastida J, Somer NU (2013). Phytochemical investigation of Galanthus woronowii. Biochemical Systematics and Ecology 51: 276-279.

Sasaki YF, Kawaguchi S, Kamaya A, Ohshita M, Kabasawa K, Iwama K, Taniguchi K, Tsuda S (2002). The comet assay with 8 mouse organs: results with 39 currently used food additives. Mutation Research/Genetic Toxicology and Environmental Mutagenesis 519: 103-119.

Singleton VL, Slinkard K (1977). Total phenol analysis: Automation and comparison with manual methods. American Journal of Enology and Viticulture 28: 49-55.

Topçu G, Erenler R, Çakmak O, Johansson CB, Çelik C, Chai H-B, Pezzuto JM (1999). Diterpenes from the berries of Juniperus excelsa. Phytochemistry 50:1195-1199.

Yaglıoglu AS, Akdulum B, Erenler R, Demirtas I, Telci I, Tekin S (2013). Antiproliferative activity of pentadeca-(8E, 13Z) dien-11-yn-2-one and (E)-1, 8-pentadecadiene from Echinacea pallida (Nutt.) Nutt. roots. Medicinal Chemistry Research 22: 2946-2953. 